\title{
Predation affects the susceptibility of hard clam Meretrix lusoria to $\mathrm{Hg}$-stressed birnavirus
}

\author{
Chung-Min Liao*, Ching-Hung Yeh, Szu-Chieh Chen \\ Department of Bioenvironmental Systems Engineering, National Taiwan University, Taipei 10617, Taiwan, ROC
}

\section{A R T I C L E I N F O}

\section{Article history:}

Received 11 April 2007

Received in revised form

20 July 2007

Accepted 30 July 2007

Published on line 14 September 2007

\section{Keywords:}

Hard clam

Predation

Birnavirus

Mercury

Predator-prey relationships

Host-pathogen-predator

interactions

Population dynamics

\begin{abstract}
A B S T R A C T
Predator-prey interaction in aquatic ecosystem is one of the simplest drivers affecting the species population dynamics. Predation controls are recognized as important aspects of ecosystem husbandry and management. In this paper we investigated how predation control cause an increase in host growth in the abundance of hard clam (Meretrix lusoria) populations subject to mercury $(\mathrm{Hg})$-stressed birnavirus. Here we linked predator-prey relationships with a bioenergetic matrix population model (MPM) associated with a susceptible-infectious-mortality (SIM) model based on a host-pathogen-predator framework to quantify the predator effects on population dynamics of disease in hard clam populations. Our results indicated that relative high predation rates could promote the hard clam abundances in relation to predators that selectively captured the infected hard clam, by which the disease transmission was suppressed. The results also demonstrated that predator-induced modifications in host behavior could have potential negative or positive effects on host growth depending on relative species density and resource dynamics. The most immediate implication of this study for the management of aquatic ecosystem is that, beyond the potential for causing a growth in abundance, predation might provoke greater predictability in aquatic ecosystem species populations and thereby increase the safety of ecosystem production from stochastic environmental events.
\end{abstract}

() 2007 Elsevier B.V. All rights reserved.

\section{Introduction}

Hard clam Meretrix lusoria, being cultured in large quantities in intertidal sandflats and ponds, was chosen for study mainly because of its economic importance in Taiwan and heavy metal pollution issues. Chou et al. (1998) indicated that an increase in heavy metal stresses such as $\mathrm{Cu}, \mathrm{Cd}, \mathrm{Hg}$, and $\mathrm{Zn}$ had a marked effect on the susceptibility of hard clam (M. lusoria) to a low pathogenic infectious pancreatic necrosis virus (IPNV)-like aquaculture birnavirus infection in that $\mathrm{Hg}$ was the most effective metal on calm growth. Our previous studies (Liao et al., 2006; Liao and Yeh, 2007) have modeled and assessed the effects of mercury $(\mathrm{Hg})$ on birnavirus infection in the $\mathrm{M}$. lusoria population, indicating that different disease transmissibility led to outbreaks characterized by basic reproductive number $\left(R_{0}\right)$, defined as the average number of secondary cases generated by one primary infected case, and the estimated allowance population numbers to control disease spread. In this paper, we emphasized on the possibility that predation risk would be more severe for infected hard clam, hypothesizing that predator control management strategy may have potential in controlling disease and consequently increase hard clam populations. Commonly found predators in hard clam included blackhead seabream (Acanthopagrus schlegelii), spotted tangingi (Scomberomorus guttatus), fiddler crab (Uca formosensis), starfish (Asteroidea), and moon shells (Neverita didyma) (http://www.water.tku.edu.tw/ sub91/frm_research/act_news_show.asp?id=25).

\footnotetext{
* Corresponding author. Tel.: +886 22363 4512; fax: +886 223626433.

E-mail address: cmliao@ntu.edu.tw (C.-M. Liao). 
Generally, infected prey are known to be more vulnerable to predation (Hudson et al., 1992; Lafferty and Morris, 1996; Mesa et al., 1998; Price and Schreck, 2003; Packer et al., 2003; Hilker et al., 2005; Hall et al., 2005; Duffy et al., 2005; Johnson et al., 2006; Fenton and Rands, 2006; Craig et al., 2006). Therefore, predators that selectively remove infected prey from a population can reduce transmission and suppress disease. Here we examined the predator control effect on prey populations that were susceptible to metalstressed infectious diseases. Several experimental studies have revealed that pathogen-induced morbidity increases vulnerability to predation (Choo et al., 2003). Packer et al. (2003) indicated that predators eliminate the most infectious individuals from the prey population, resulting in an outcome equivalent to quarantine, i.e., infectious individuals are removed from the healthy population and thereby prevented from spreading disease. Although predators may be most likely to capture infected prey, possible consequences are considered when predators preferentially select healthy prey, implicating that predators may play an even more critical role in host-pathogen dynamics (Hall et al., 2005).

Mathematical models described by a host-pathogenpredator framework have been developed to study the effect of a pathogen of the prey on an existing predator-prey interaction (Grenfell and Dobson, 1995). Recently developed mathematical models based on the host-pathogen-predator scheme have shown that the impact of host manipulation depends greatly on the predation rates, which describes the predating behavior under changing prey availabilities (Choo et al., 2003; Packer et al., 2003; Hilker et al., 2005; Hall et al., 2005; Johnson et al., 2006; Fenton and Rands, 2006).

In the present study, we presented mathematical models associated with extensive simulation scenarios that coupled Hg-stressed binarvirus transmission and pathogenicity to estimate the impact of predating behavior on the survival of hard clam populations and to characterize the circumstances where metal-stressed disease can become more harmful to hard clam populations after predators have been eliminated or reduced. Scenario-dependent management strategies on hard clam abundance and the impact of predator preference for infected vs. healthy hard clam were evaluated to determine the disease spreading and allowance health hard clam numbers to control disease outbreak.

We investigated the population dynamic interactions between metal-stressed disease and predator-prey relationships in hard clam using a dynamic link to empirical data and a host-pathogen-predator model. The analysis yields quantitative insights into the mechanisms and extent of impacts of predator control on disease dynamics in hard clam populations. More generally, the results inform the development of ecosystem conservation and disease theory and its applications in fisheries and aquatic ecosystem management.

\section{Materials and methods}

\subsection{Stage-structured hard clam-birnavirus-predator system}

Based on the previous developed models (Liao et al., 2006; Liao and Yeh, 2007) that link a stage-structured matrix

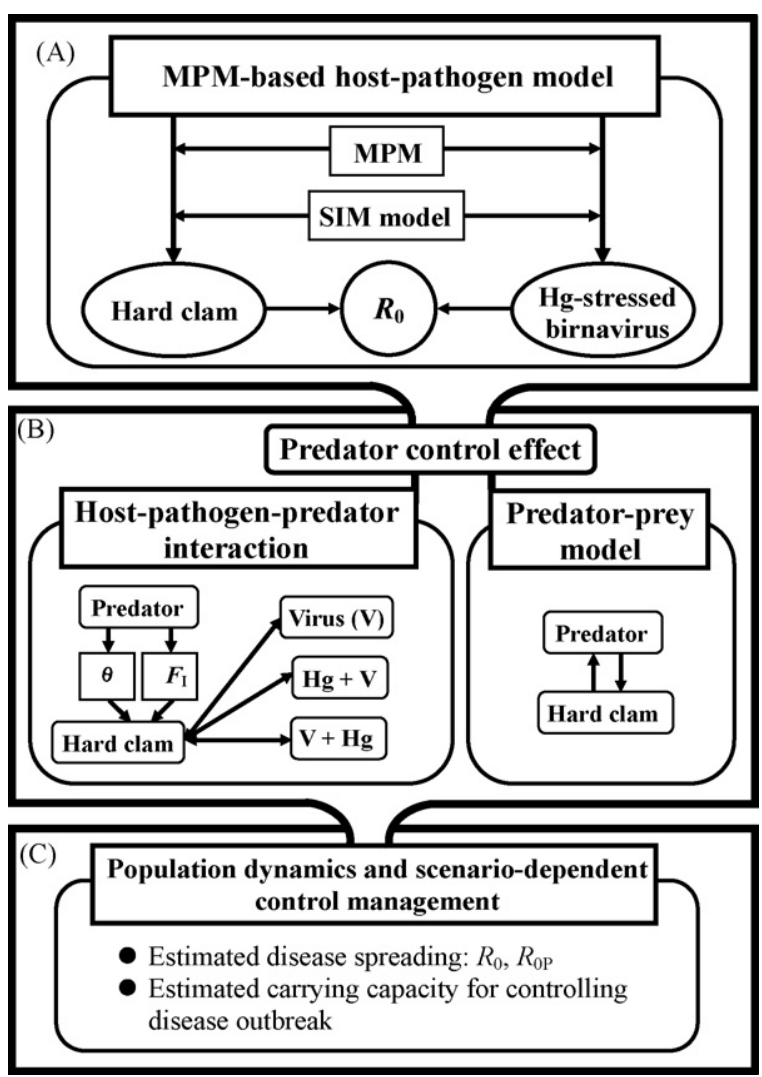

Fig. 1 - A conceptual algorithm showing an analytical framework to describe the predation effects on hard clam to Hg-stressed birnavirus susceptibility including (A) matrix population based host-pathogen model. (B) Linkage of host-pathogen-predator interactions and predator-prey relationships, and (C) aquatic ecosystem management strategies. The $R_{0}$ is the basic reproductive number, $\theta$ is the selectivity of predators on infected hosts, $F_{\mathrm{I}}$ is the selectivity of predators that only capture infected hosts, and $R_{0 P}$ is the basic reproductive number with predation.

population model (MPM) associated with a deterministic susceptible-infectious-mortality (SIM) model and a nonlinear epidemiological dynamics of host-pathogen model (Fig. 1A, Table 1), we formulated a host-pathogen-predator model to quantify the predation effects on population dynamics of disease in hard clam populations subjected to Hg-stressed birnavirus (Fig. 1B and C). The stage-structure MPM is based on a four-stage (embryos/larvae to juveniles to sub-adults to adults) matrix model used to project offspring production through two generations based on the body weight as suggested by Fisheries Administration, Council of Agriculture, ROC (http://www.fagov.tw/chn/index.php), indicating that the duration of each life stage of hard clam was estimated to be $3,5,8$, and 16 months, respectively, yielding a life span of 32 months.

The nonlinear epidemiological dynamics of host-pathogen model is based on an analysis of the dynamics of host-pathogen interactions in a homogeneous host population subjected to an environmental chemical stress of exposed concentration $\mathrm{C}$. We do this by studying the ability of a 
Table 1 - Previous developed matrix population model (MPM)-susceptible-infected-mortality (SIM) model associated with population dynamics of disease model (Liao et al., 2006; Liao and Yeh, 2007)

Matrix population model

$\left\{\begin{array}{l}n_{1} \\ n_{2} \\ n_{3} \\ n_{4}\end{array}\right\}(t+1)=\left[\begin{array}{cccc}P_{1} & 0 & F_{3} & F_{4} \\ G_{1} & P_{2} & 0 & 0 \\ 0 & G_{2} & P_{3} & 0 \\ 0 & 0 & G_{3} & P_{4}\end{array}\right]\left\{\begin{array}{l}n_{1} \\ n_{2} \\ n_{3} \\ n_{4}\end{array}\right\}(t)$

SIM model

$$
\frac{\mathrm{d} S}{\mathrm{dt}}=-\beta(\mathrm{C}) \mathrm{SI}, \quad \frac{\mathrm{dI}}{\mathrm{dt}}=\beta(\mathrm{C}) \mathrm{SI}-\alpha(\mathrm{C}) \mathrm{I}, \quad \frac{\mathrm{dM}}{\mathrm{dt}}=\alpha(\mathrm{C}) \mathrm{I},
$$

Basic reproductive number, $R_{0}$

$\mathrm{R}_{0}(C)=\frac{\mathrm{N}(0) \beta(C)}{\alpha(C)}$,

Pollution-stressed population dynamics of disease model

$$
\begin{aligned}
& I=1-\exp \left(1.63-1.66 R_{0}(C)\right) ; \quad 0.98<R_{0}(C)<5 \\
& N(t+1)=N(t) \exp \left[(\ln \lambda(C)+1.63)\left(1-\frac{1.66}{((1.63+\ln \lambda(C)) /(N \beta(C) / \alpha(C)))}\right)\right],
\end{aligned}
$$

See text for the symbol meanings.

lethal waterborne pathogen with the exposed concentrationdependent virulence $\alpha(C)$ and the transmissibility $\beta(C)$, to invade an aquaculture species population in a polluted aquatic ecosystem. The waterborne pathogen spreads in an epidemic fashion throughout each generation before reproductive maturity is attained. The survivors then go on to reproduce, each producing on average offspring characterizing by a population growth rate as a function of exposed concentration $(\lambda(C))$ that survive to emerge as adults at the start of the next generation (Anderson and May, 1991).

A diagram of the present models describing the predator-prey interaction and stage-structured hard clam-birnavirus-predator system is given in Fig. 2. We began by modeling a simple stage-structured hard clam-Hg-predator interaction in a predator-prey model (Fig. 2A),

$$
\begin{aligned}
& \frac{d S_{1}}{d t}=-S_{1}\left(1-P_{1}\right)+S_{3} F_{3}+S_{4} F_{4}-p f S_{1} P_{1}, \\
& \frac{d S_{2}}{d t}=S_{1} G_{1}-S_{2}\left(1-P_{2}\right)-p f S_{2} P_{2}, \\
& \frac{d S_{3}}{d t}=S_{2} G_{2}-S_{3}\left(1-P_{3}\right)-p f S_{3} P_{3}, \\
& \frac{d S_{4}}{d t}=S_{3} G_{3}-S_{4}\left(1-P_{4}\right)-p f S_{4} P_{4},
\end{aligned}
$$

where $S_{i}$ is the susceptible in stage $i, P_{i}$ is the probability of surviving and staying in stage $i, G_{i}$ is the probability of surviving and growing from stage $i$ to stage $i+1$, and $F_{i}$ is the per capita fertility of stage $i$ within each projection interval, $p$ is the predator density (ind), and $f$ is the predation rate (ind ${ }^{-1}$ day $^{-1}$ ).

We further extended Eq. (1) to a stage-structured hard clam-Hg-birnavirus-predator system by incorporating a disease-induced SIM dynamics into a MPM-host-pathogen-predator model (Fig. 2B) and parameterized this model using published data on the hard clam subjected to Hg-stressed birnavirus environment. The dynamics of this model within one growing season are described as follows:
Stage 1 (embryo/larva):

$$
\begin{aligned}
& \frac{d S_{1}}{d t}=S_{3} F_{3}+S_{4} F_{4}-S_{1}\left(1-P_{1}\right)-\left(\lambda_{F_{1}}+p f^{*}\right)\left(S_{1} P_{1}\right), \\
& \frac{d I_{1}}{d t}=\lambda_{F_{1}}\left(S_{1} P_{1}\right)+I_{3} \hat{F}_{3}+I_{4} \hat{F}_{4}-I_{1}\left(1-\hat{P}_{1}\right)-\left(\alpha_{1}+\theta p f\right)\left(I_{1} \hat{P}_{1}\right), \\
& \frac{d M_{1}}{d t}=\alpha_{1}\left(I_{1} \hat{P}_{1}\right),
\end{aligned}
$$

Stage 2 (juvenile):

$$
\begin{aligned}
& \frac{d S_{2}}{d t}=S_{1} G_{1}-S_{2}\left(1-P_{2}\right)-\left(\lambda_{F_{2}}+p f^{*}\right)\left(S_{2} P_{2}\right), \\
& \frac{d I_{2}}{d t}=\lambda_{F_{2}}\left(S_{2} P_{2}\right)+I_{1} \hat{G}_{1}-I_{2}\left(1-\hat{P}_{2}\right)-\left(\alpha_{2}+\theta p f\right)\left(I_{2} \hat{P}_{2}\right), \\
& \frac{d M_{2}}{d t}=\alpha_{2}\left(I_{2} \hat{P}_{2}\right),
\end{aligned}
$$

Stage 3 (sub-adult):

$$
\begin{aligned}
& \frac{d S_{3}}{d t}=S_{2} G_{2}-S_{3}\left(1-P_{3}\right)-\left(\lambda_{F_{3}}+p f^{*}\right)\left(S_{3} P_{3}\right), \\
& \frac{d I_{3}}{d t}=\lambda_{F_{3}}\left(S_{3} P_{3}\right)+I_{2} \hat{G}_{2}-I_{3}\left(1-\hat{P}_{3}\right)-\left(\alpha_{3}+\theta p f\right)\left(I_{3} \hat{P}_{3}\right), \\
& \frac{d M_{3}}{d t}=\alpha_{3}\left(I_{3} \hat{P}_{3}\right),
\end{aligned}
$$

Stage 4 (adult):

$$
\begin{aligned}
& \frac{d S_{4}}{d t}=S_{3} G_{3}-S_{4}\left(1-P_{4}\right)-\left(\lambda_{F_{4}}+p f^{*}\right)\left(S_{4} P_{4}\right), \\
& \frac{d I_{4}}{d t}=\lambda_{F_{4}}\left(S_{4} P_{4}\right)+I_{3} \hat{G}_{4}-I_{4}\left(1-\hat{P}_{4}\right)-\left(\alpha_{4}+\theta p f\right)\left(I_{4} \hat{P}_{4}\right), \\
& \frac{d M_{4}}{d t}=\alpha_{4}\left(I_{4} \hat{P}_{4}\right),
\end{aligned}
$$

where $\hat{P}_{i}, \hat{G}_{i}$, and $\hat{F}_{i}$ are probabilities of surviving and staying, surviving and growing, and fertility within each projection interval in stage $i$ at an infected condition, $\lambda_{F}$, is the force 

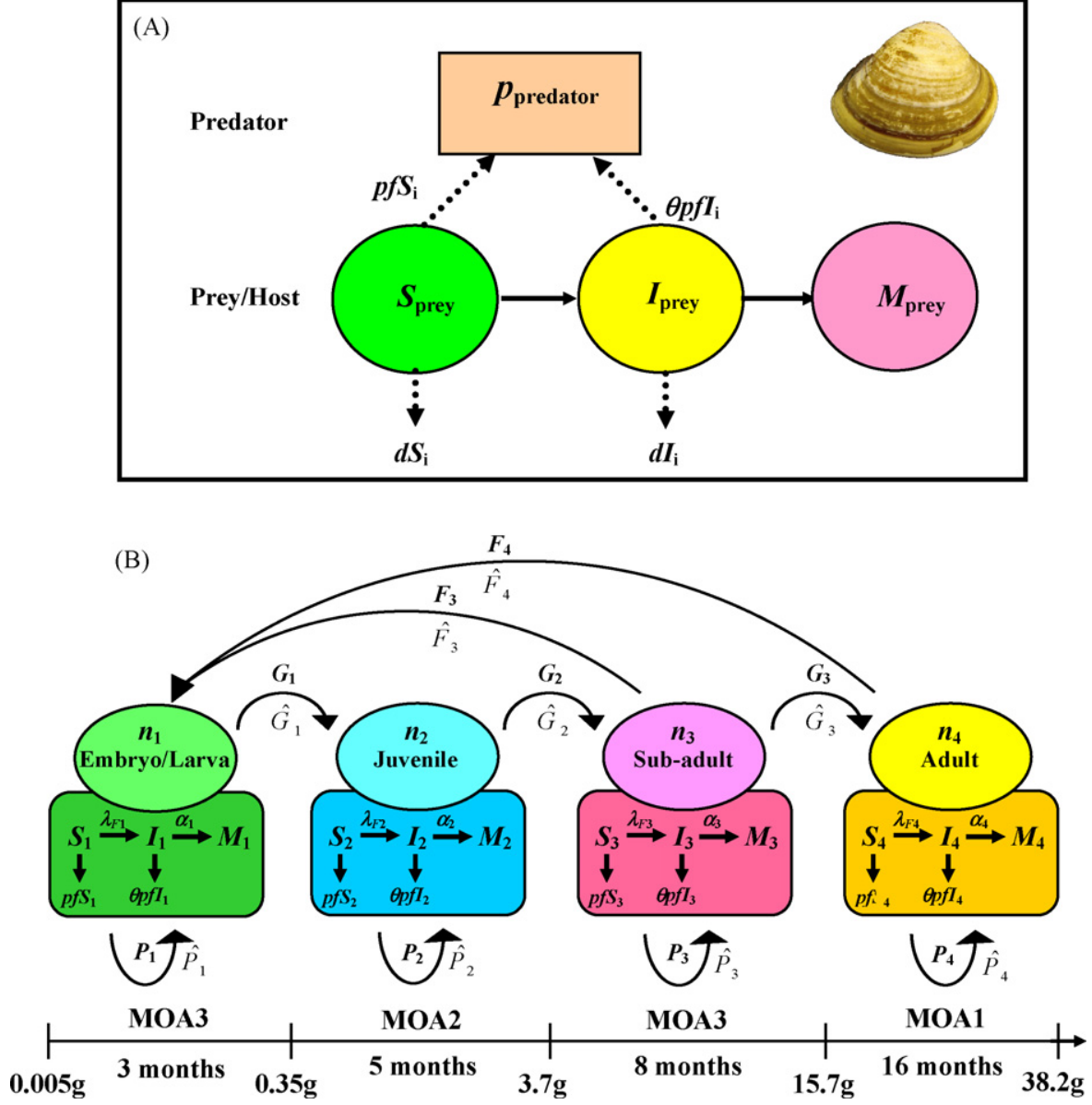

Fig. 2 - Schematic representation of host-pathogen-predator interactions. (A) Disease transmission model links predator-prey model. (B) A four-stage life cycle graph of an individual hard clam (M. lusoria) exposed to Hg-stressed birnavirus associated with predation control. The $p f$ is the predator attack rate, $n_{i}$ means density of host in stage $i, d$ means nature mortality, $\lambda_{F_{i}}$ is the force of infection, $\alpha$ is the disease-induced mortality rate, $\theta$ is the selectivity of predators on infected hosts; vital rates of $P_{i}, G_{i}$, and $F_{i}$ are the probabilities of surviving and staying, surviving and growing, and fertility of stage $i$ within each interval, respectively.

of infection that is the infection pressure experienced by one susceptible individual and is given by $\lambda_{\mathrm{F}}=\beta(\mathrm{C}) \mathrm{I}(\mathrm{t}), \mathrm{f}^{*}$ is a conditional predation rate and is equal to zero when predators only capture infected prey and we use $F_{I}$ to characterize this effort, and $\theta$ is the selectivity of predators on infected individuals. Hence, when $\theta=1$ implies that predators have no preference at all, i.e., infected hosts are likely to be preyed upon as healthy hosts, when $\theta>1$ indicate that predators prefer infected to susceptible hosts, and when $0<\theta<1$ means that predators prefer susceptible hosts to infected hosts (Lafferty, 1992; Hall et al., 2006; Fenton and Rands, 2006). Thus, $F_{I}$ can be seen as $\theta \rightarrow \infty$.

Three modes of toxic action (MOA1, MOA2, and MOA3) were distinguished on the $\mathrm{Hg}$ growth inhibition of hard clam population model (Fig. 2B): (1) before production of offspring, uninfected hard clams allocated energy to shell growth and glycogen storage, i.e., increase growth cost (MOA3) on embryo/larva and sub-adult stages, (2) during offspring production shell growth slows down, hard clams lost weight and consume the stored glycogen, i.e., decreased assimila- tion (feeding) (MOA1) on adult stage, and (3) the fat content of hard clams increased on juveniles indicating increased the maintenance costs (MOA2) on that stage. The MOA1, MOA2, and MOA3 can be defined as follows (Tsai and Liao, 2006). MOA1: When feeding was decreasing, growth reduction acted through reducing the incoming energy, MOA 2: when maintenance energy cost was increasing, chemicals were likely to increase in maintenance costs for compensating for the effects of exposure (Beyers et al., 1999), and MOA 3: in case of increase growth energy cost, the metabolic energy will be required to create a new cell. The detailed mechanistic models of MOA1, MOA2, and MOA3 can be found in Liao and Yeh (2007).

Pollution-stressed basic reproductive number in a predator-prey model $\left(R_{\mathrm{OP}}(C)\right)$ can be calculated based on $\beta(C)$ and $\alpha(C)$ associated with predator attack rate $(p f)$ and the initial host population size $(\mathrm{N}(0))$ as,

$\mathrm{R}_{0 \mathrm{P}}(C)=\frac{N(0) \beta(C)}{\alpha(C)+p f}$ 
Table 2 - Input parameters of vital rates and disease transmission of individual hard clam used in MPM-SIM model (Liao and Yeh, 2007)

\begin{tabular}{|c|c|c|c|c|}
\hline & Stage $1(i=1)$ & Stage $2(i=2)$ & Stage $3(i=3)$ & Stage $4(i=4)$ \\
\hline \multicolumn{5}{|l|}{ Vital rate parameters } \\
\hline \multicolumn{5}{|l|}{$G_{i}$} \\
\hline \multicolumn{5}{|l|}{ Without disease } \\
\hline $0^{\mathrm{a}}$ & $0.0476(0.0440-0.0509)$ & $0.0158(0.0157-0.0159)$ & $0.0060(0.0053-0.0062)$ & $0.0019(0.0016-0.0021)$ \\
\hline $5^{a}$ & $0.0467(0.0438-0.0493)$ & $0.0158(0.0145-0.0158)$ & $0.0059(0.0053-0.0063)$ & $0.0018(0.0016-0.0022)$ \\
\hline $10^{\mathrm{a}}$ & $0.0466(0.0436-0.0490)$ & $0.0153(0.0143-0.0156)$ & $0.0059(0.0052-0.0063)$ & $0.0018(0.0016-0.0021)$ \\
\hline \multicolumn{5}{|l|}{ With disease } \\
\hline $\mathrm{V}^{\mathrm{b}}$ & $0.0447(0.0413-0.0477)$ & $0.0147(0.0146-0.0147)$ & $0.0056(0.0053-0.0057)$ & $0.0017(0.0015-0.0020)$ \\
\hline $\mathrm{V}+5^{\mathrm{b}}$ & $0.0287(0.0273-0.0298)$ & $0.0033(0.0032-0.0033)$ & $0.00050(0.00050-0.00051)$ & $0.00007(0.00007-0.00008)$ \\
\hline $5+V^{b}$ & $0.0089(0.0084-0.0094)$ & $0.0001(0.0001-0.0002)$ & $0.00001(0.00001-0.00001)$ & $0.00001(0.00001-0.00002)$ \\
\hline \multicolumn{5}{|l|}{$P_{i}$} \\
\hline \multicolumn{5}{|l|}{ Without disease } \\
\hline 0 & 0.9482 (0.9440-0.9528) & $0.9821(0.9817-0.9826)$ & 0.9925 (0.9924-0.9948) & 0.9907 (0.9902-0.9939) \\
\hline 5 & $0.9492(0.9457-0.9530)$ & $0.9825(0.9828-0.9828)$ & 0.9926 (0.9925-0.9929) & 0.9906 (0.9902-0.9938) \\
\hline 10 & $0.9491(0.9457-0.9531)$ & $0.9821(0.9821-0.9825)$ & $0.9921(0.9920-0.9923)$ & $0.9900(0.9901-0.9936)$ \\
\hline \multicolumn{5}{|l|}{ With disease } \\
\hline $\mathrm{V}$ & $0.8894(0.8862-0.8943)$ & 0.9163 (0.9159-0.9169) & $0.9260(0.9259-0.9282)$ & $0.9265(0.9256-0.9273)$ \\
\hline$V+5$ & $0.5829(0.5710-0.5952)$ & $0.2105(0.2051-0.2167)$ & $0.0867(0.0796-0.0946)$ & $0.0379(0.0330-0.0435)$ \\
\hline $5+V$ & $0.1806(0.1806-0.1832)$ & $0.0091(0.0062-0.0136)$ & $0.0020(0.0011-0.0037)$ & $0.0006(0.0003-0.0012)$ \\
\hline \multicolumn{5}{|l|}{$F_{i}$} \\
\hline \multicolumn{5}{|c|}{ Without and with disease } \\
\hline $0, \mathrm{~V}$ & - & - & $0.0094(0.0050-0.0171)$ & $0.0024(0.0021-0.0025)$ \\
\hline $5, V+5,5+V$ & - & - & $0.0092(0.0043-0.0170)$ & $0.0023(0.0021-0.0023)$ \\
\hline 10 & - & - & $0.0092(0.0043-0.0170)$ & $0.0023(0.0021-0.0023)$ \\
\hline \multicolumn{5}{|c|}{ Disease transmission parameters } \\
\hline \multicolumn{5}{|c|}{$\beta_{\mathrm{i}}$} \\
\hline \multicolumn{2}{|l|}{$\mathrm{V}$} & \multicolumn{2}{|c|}{$0.0012(0.0006-0.0020)$} & \\
\hline \multicolumn{2}{|l|}{$V+5$} & \multicolumn{2}{|c|}{$0.0085(0.0074-0.0096)$} & \\
\hline \multicolumn{2}{|l|}{$5+V$} & \multicolumn{2}{|c|}{$0.0197(0.0165-0.0226)$} & \\
\hline \multicolumn{5}{|l|}{$\alpha_{\mathrm{i}}$} \\
\hline \multicolumn{2}{|l|}{$\mathrm{V}$} & \multicolumn{2}{|c|}{$0.0752(0.0375-0.1214)$} & \\
\hline \multicolumn{2}{|l|}{$V+5$} & \multicolumn{2}{|c|}{$0.517(0.444-0.582)$} & \\
\hline \multicolumn{2}{|l|}{$5+V$} & \multicolumn{2}{|c|}{$1.161(0.971-1.337)$} & \\
\hline
\end{tabular}

\subsection{Model parameterization and simulation scheme}

Table 2 gives the used numerical values of vital rates $(G, P$, and F) and disease transmission parameters $(\beta$ and $\alpha)$ of individual hard clam in four stages in MPM-SIM model in that the symbol meanings associated with the host-pathogen-predator parameters is listed in Table 3. The disease data were adopted from the laboratory disease challenge experiments in studying the effects of heavy metal on the susceptibility of M. lusoria to clam-birnavirus infection (Chou et al., 1998). Chou et al. (1998) conducted two experiments to examine the effects of $\mathrm{Hg}$ on the disease transmission in hard clam: In experiment I (denoting as $\mathrm{V}+\mathrm{Hg}$ ), group of 60 clams were immersed in birnavirus solution for $24 \mathrm{~h}$ and subsequently exposed to different $\mathrm{Hg}$ concentrations. In experiment II (denoting as $\mathrm{Hg}+\mathrm{V}$ ), clams were exposed to $\mathrm{Hg}$ for 7 days and then infected with birnavirus in that controls were only exposed to $\mathrm{Hg}$.

The major results in experiment I indicated that cumulative mortalities of clams were $20-50 \%$ in most of the experimental groups after 5 weeks, whereas in experiment II the survival time shortened and the mortalities ranged from 65 to $90 \%$. To manipulate the simulation of stage-structured population growth model, a projection interval of 1 day was used. Caswell (2001) pointed out that the initial condition had no influence on the stable age distributions as well as population growth rate. Here 60 hard clams were used as the initial number in each stage in accordance with the experimental condition conducted by Chou et al. (1998).

Model simulations and the determinations of asymptotic population growth rate under different scenarios were performed using the MATLAB ${ }^{\circledR}$ software (The Mathworks Inc., MA, USA). We used a Monte Carlo simulation to quantify the uncertainty by employing Crystal Ball software (Version 2000.2, Decisioneering, Inc., Denver, CO, USA). For this study, 10,000 iterations were sufficient to ensure stability of results. The $95 \%$ confidence interval (CI) is defined as the 2.5th and 97.5th percentiles obtained from the Monte Carlo simulation. 
Table 3 - Symbol meanings and values of variables and parameters used in host-pathogen-predator model

\begin{tabular}{|c|c|c|}
\hline Symbol (units) & Definition & Value \\
\hline$n_{i}$ (ind) & Density of host in stage $i$ & 60 \\
\hline$S_{i}$ (ind) & Density of susceptibles & - \\
\hline$I_{i}$ (ind) & Density of infected & - \\
\hline $\mathrm{M}_{\mathrm{i}}$ (ind) & Density of mortality & - \\
\hline$\beta$ (ind $^{-1}$ day $^{-1}$ ) & Transmission rate & See Table 2 \\
\hline$\alpha\left(\right.$ day $\left.^{-1}\right)$ & $\begin{array}{l}\text { Disease-induced mortality } \\
\text { rate }\end{array}$ & See Table 2 \\
\hline$\lambda_{F_{i}}\left(\right.$ day $\left.^{-1}\right)$ & Force of infection & $\beta_{i}(C) I$ \\
\hline$P_{i}, \hat{P}_{i}\left(\right.$ day $\left.^{-1}\right)$ & $\begin{array}{l}\text { Probability of surviving and } \\
\text { staying }\end{array}$ & See Table 2 \\
\hline$G_{i}, \hat{G}_{i}\left(\right.$ day $\left.^{-1}\right)$ & $\begin{array}{l}\text { Probability of surviving and } \\
\text { growing }\end{array}$ & See Table 2 \\
\hline$F_{i}, \hat{F}_{i}\left(\right.$ day $\left.^{-1}\right)$ & $\begin{array}{l}\text { Fertility of stage } i \text { within } \\
\text { each interval }\end{array}$ & See Table 2 \\
\hline$p$ (ind) & Density of predators & Constant \\
\hline$f\left(\right.$ ind $^{-1}$ day $\left.^{-1}\right)$ & Predation rate & Constant \\
\hline$p f\left(\right.$ day $\left.^{-1}\right)$ & Predator attack rate & $0.0005-0.5$ \\
\hline$\theta$ & $\begin{array}{l}\text { Selectivity of predators on } \\
\text { infected hosts }\end{array}$ & 1,9 \\
\hline$F_{\mathrm{I}}$ & $\begin{array}{l}\text { Selectivity of predators that } \\
\text { only capture infected hosts }\end{array}$ & $\theta \rightarrow \infty$ \\
\hline$R_{0}$ & Basic reproductive number & - \\
\hline$R_{O P}$ & $\begin{array}{l}\text { Basic reproductive number } \\
\text { with predation }\end{array}$ & - \\
\hline
\end{tabular}

\section{Results}

\section{1. $\mathrm{Hg}$-stressed predator-prey interaction in hard} clam populations

The temporal changes of overall population abundance of infected hard clam population exposed to different scenarios of waterborne $\mathrm{Hg}$ with different levels of predator attack rate ( $p f)$ were depicted in Fig. 3 in that the simulation time period was determined from a pre-analysis for the control population to reach its stable age distribution. At a relative high predator pressure (high $p f$ value), the hard clam populations decrease sharply (Fig. 3A). Fig. 3B reveals that at a nearly 1-year simulation period, $0 \mu \mathrm{g} \mathrm{Hg} \mathrm{L}^{-1}+$ low $p f, 5 \mu \mathrm{g} \mathrm{Hg} \mathrm{L}^{-1}+$ low pf, and $10 \mu \mathrm{g} \mathrm{Hg} \mathrm{L}^{-1}$ have similar effects on the hard clam abundances. Fig. 3B also demonstrates that the combined effects of high predator attack rate and environmental $\mathrm{Hg}$ stressor could account for nearly all of the elimination of hard clam populations.

\subsection{Hg-stressed host-pathogen-predator interactions in hard clam populations}

The simulation results reveal that different experimental settings $\left(\mathrm{V}, \mathrm{V}+5 \mu \mathrm{gHgL}^{-1}\right.$, and $\left.5 \mu \mathrm{gHgL}^{-1}+\mathrm{V}\right)$ had significantly different hard clam population abundance dynamics based on $N_{i}(0)=60$ varied with selective predation $\left(\theta, F_{I}\right)$ and the levels of predator attack rate ( $p$ ) (Figs. 4-6). In the V only setting, the effects of predator attack rate level are more significant than that of selective predation on the hard clam abundance (Fig. 4). When predators only captured infected hard clam, at a relative high predator attack rate condition, the predation increases the hard clam abundance very considerably, implicating that
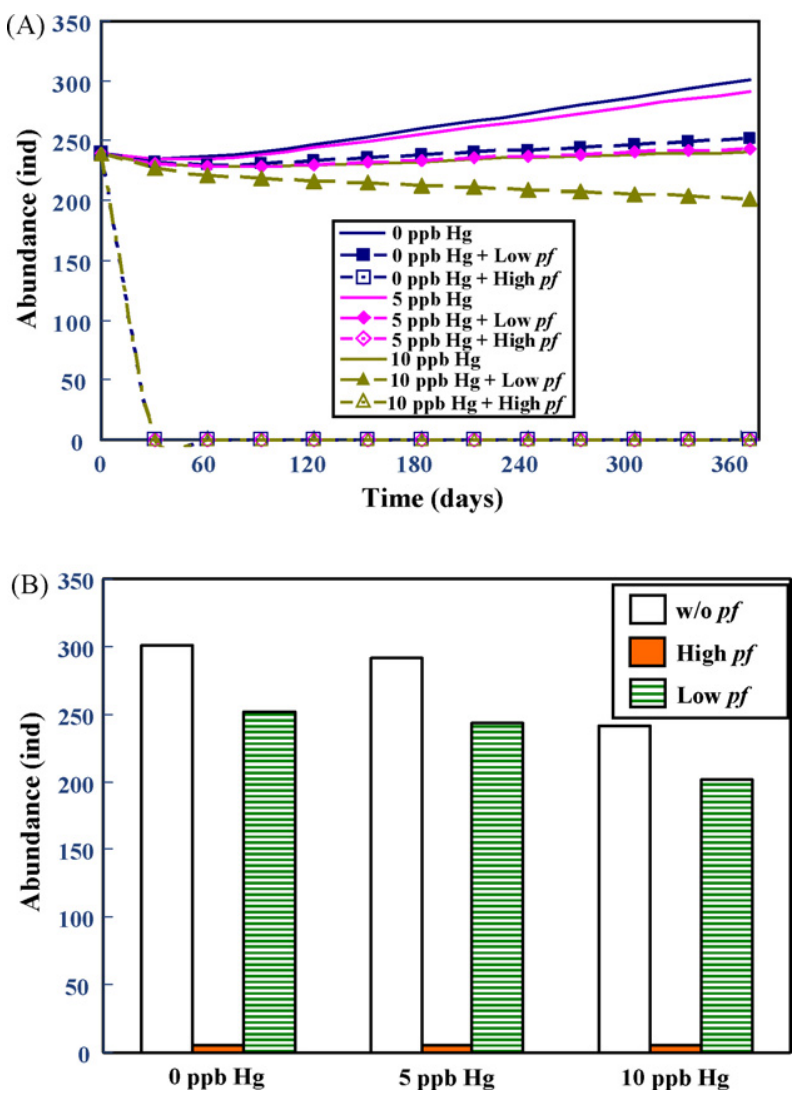

Fig. 3 - Simulations of predator-prey interactions varied with different levels of predation attack rates (pf). (A) Dynamics of hard clam abundances exposed to 0,5 , and $10 \mu \mathrm{g} \mathrm{Hg} \mathrm{L}^{-1}$ with/without predation effects. (B) A 1-year simulation of predation effects on hard clam exposed to waterborne $\mathrm{Hg}$.

predator involved can increase the number of healthy individuals in the hard clam populations and reduce the incidence of pathogenic infection (Fig. 4B).

The model predicts that, in the $\mathrm{V}+5 \mu \mathrm{gHgL}^{-1}$ setting, selective predations ( $\theta=1$ and 9 ) with low level of predator attack rate of $p f$ favor the hard clam population abundance, whereas high level of $p f$ can totally eliminate the hard clam population at day 30 (Fig. 5). High predator attack rate of pf associated with the $F_{I}$ effort of the infected hard clam are all captured by the predators, indicating a more significant effect on the increase of population abundance than that of at low predator attack rate (Fig. 5B).

In the $5 \mu \mathrm{g} \mathrm{Hg} \mathrm{L}^{-1}+\mathrm{V}$ setting, the model predicts that the overall hard clam populations decreased sharply nearly $80 \%$ of control number at day 30 , then steadily grew to the end of the year, implicating that $\mathrm{Hg}$ stress and predation affect the population dynamics of disease transmission in hard clam populations (Fig. 6). The predicted results were sensitive to substantial changes in the levels of predator attack rate ( $p f$ ) that would affect dynamics most strongly and even to changes in aspects of model structure (Fig. 6A and B). Selective predations from no manipulation $(\theta=1)$ to infected hard clams are more attractive than uninfected $(\theta=9)$ associated with high predator attack rate ( $p f)$ having efforts on totally elimination 

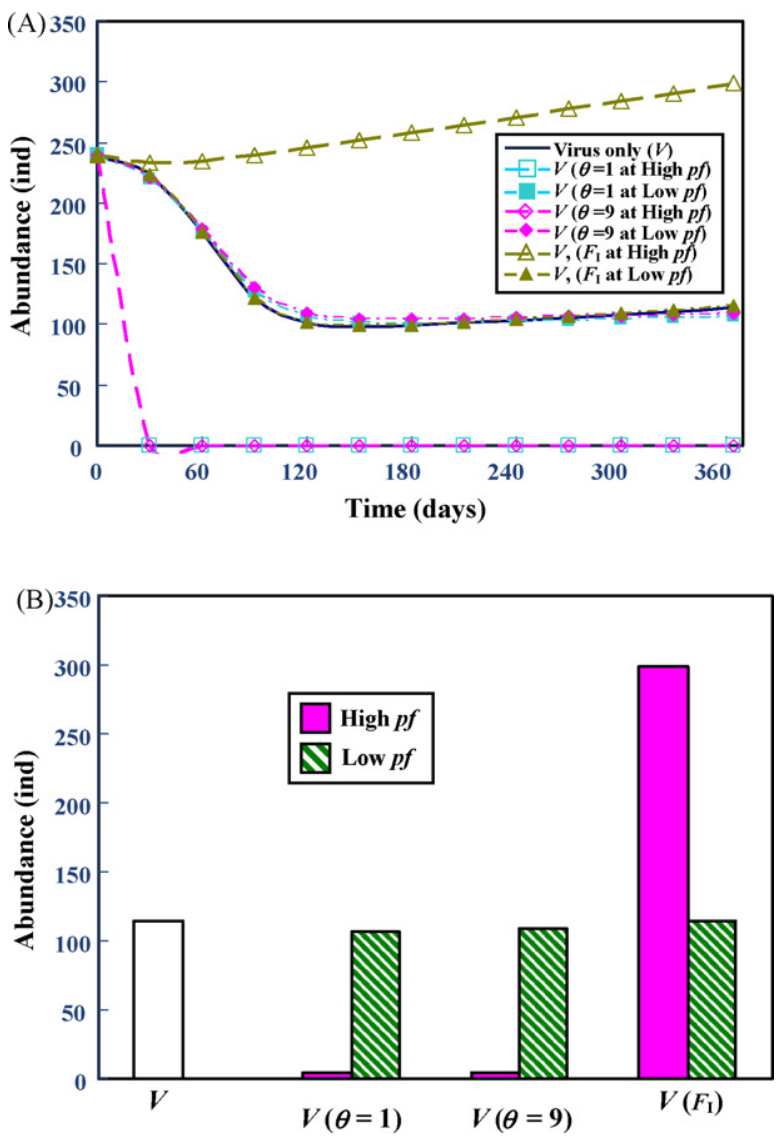

Fig. 4 - Simulations of host-pathogen-predator interactions without $\mathrm{Hg}$ (virus only scenario) varied with different levels of predation attack rates (pf). (A) Dynamics of hard clam population abundances infected by birnavirus at selectivity of predation $\theta=1,9$, and $F_{I}(\theta \rightarrow \infty)$. (B) A 1-year simulation of predation effects on hard clam infected by virus with high/low predation control.

of hard clam populations, whereas when infected hard clam are all captured by predators ( $F_{I}$ effort), high and low $p f$ having the similar effects on population abundances (Fig. 6C).

\subsection{Quantitative management strategies}

Hard clam populations undergoing Hg-stressed birnavirus presented a unique spread pattern that led us to study the dynamics of infectious diseases linked with MPM-SIM and host-pathogen-predator interactions. Based on theoretical considerations in the present framework, we outlined three qualitatively distinct scenarios of $\mathrm{V}, \mathrm{V}+5 \mu \mathrm{g} \mathrm{Hg} \mathrm{L}^{-1}$, and $5 \mu \mathrm{ggL}^{-1}+\mathrm{V}$ with different levels of predator attack rate. Within a range of disease transmissibility drawn from analysis of birnavirus in hard clams, different levels of predation rate led to disease outbreaks characterized by basic reproductive number with predation $\left(R_{0 P}\right)$ and the estimated allowance population numbers $\left(\mathrm{N}^{*}\right)$ to contain disease spread for all three scenarios (Fig. 7 and Table 4).

Predator attack rate $(p f)$ reduces the basic reproductive number very considerably in three considered scenarios in that high $p f$ value gives a significant effect than that of low $p f$
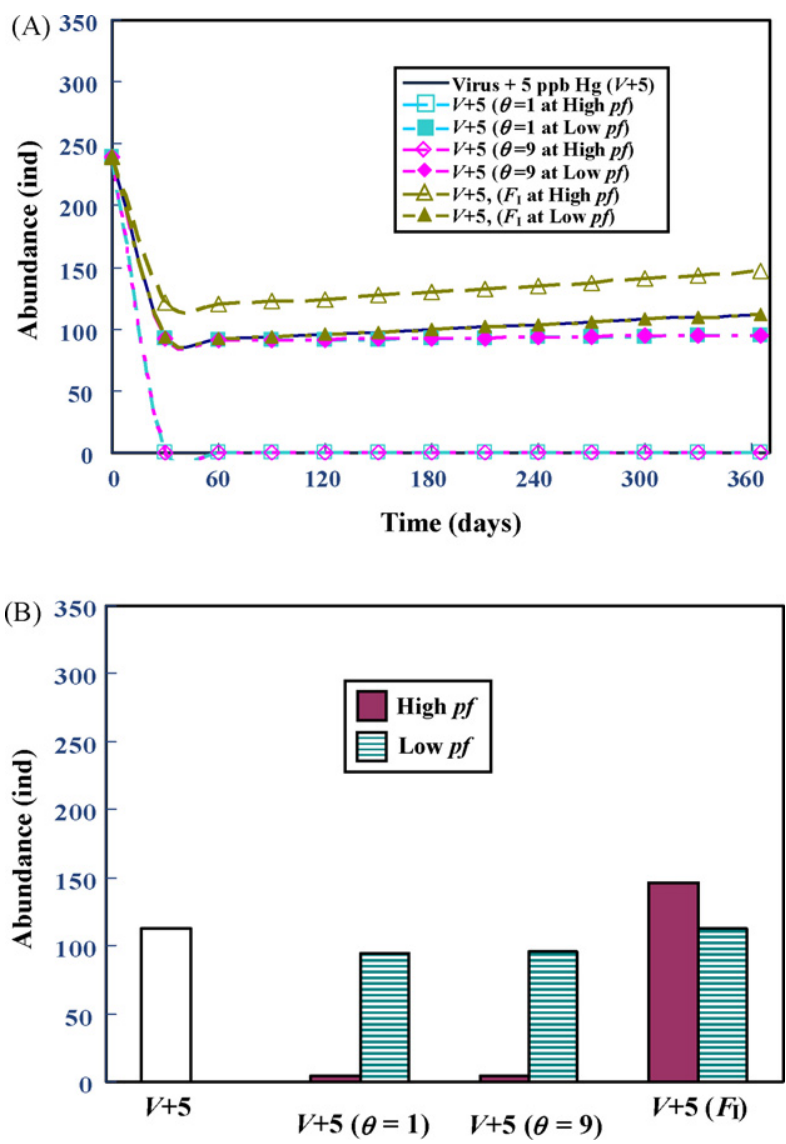

Fig. 5 - Simulations of host-pathogen-predator interactions varied with different levels of predation attack rates $(p f)$ at $5 \mu \mathrm{g} \mathrm{L}^{-1} \mathrm{Hg}+$ virus $(5+\mathrm{V})$ setting. (A) Dynamics of hard clam exposed to $5+V$ at $\theta=1,5$, and $F_{I}(\theta \rightarrow \infty)$. (B) A 1-year simulation of predation effects on hard clam exposed to $5+V$ setting with high/low predation control.

value on reducing $R_{0 P}\left(R_{O P}\right.$ were reducing from 3.93 to $0.51,4.09$ to 2.86 , and 3.95 to 1.90 , respectively, at $\mathrm{V}, 5 \mu \mathrm{gg} \mathrm{L}^{-1}+\mathrm{V}$, and $\mathrm{V}+5 \mu \mathrm{g} \mathrm{HgL}^{-1}$ settings) (Fig. 7 and Table 4). Table 4 indicates that at relative high predation rates, the estimated allowance rearing numbers of hard clam to control the potential outbreak are 83 and 124, respectively, in the $5 \mu \mathrm{g} \mathrm{HgL}^{-1}+\mathrm{V}$ and $\mathrm{V}+5 \mu \mathrm{gHgL}^{-1}$ settings with the $\mathrm{R}_{\mathrm{OP}}$ around $1.90-2.86$. Table 4 also implicates that limitation of host size or carrying capacity is one of the most effective control management strategies in a host-pathogen-predator interaction in the aquatic ecosystem.

\section{Discussion}

Predation-prey interaction in ecosystem is one of the simplest drivers that can be imaged on affecting population dynamics of the aquatic ecosystem species (Mesa et al., 1994; Price and Schreck, 2003; Fregadolli, 2003; Gibbs, 2004; Stotz et al., 2006; Greene and Grizzle, 2007). Our present MPM-SIM-predator model based on the host-pathogen-predator framework predicted that the outcome of this predation effect on population dynamics of disease in hard clam populations subjected to Hg-stressed birnavirus was simple: a relative high selective 
Table 4 - Management strategies: scenario-dependent estimated basic reproductive number and allowance carrying capacity to contain disease outbreak

\begin{tabular}{lcr} 
Scenarios & $\begin{array}{c}\text { Estimated } \\
\text { median } R_{0}, R_{0 P}\end{array}$ & $\begin{array}{c}\text { Estimated allowance numbers } \\
\text { to control outbreak }\left(N^{*}\right)\end{array}$ \\
\hline Host-pathogen model & & 61.0 \\
Virus only (V) & 3.93 & 466.8 \\
V (high pf) & 0.51 & 65.1 \\
V (low pf) & 3.69 & 57.6 \\
Host-pathogen-predator model & & 82.4 \\
5 ppb Hg+virus (5+V) & 4.09 & 57.8 \\
5+V (high pf) & 2.86 & 59.5 \\
5 +V (low pf) & 4.07 & 123.9 \\
Virus + 5 ppb Hg (V+5) & 3.95 & 60.1 \\
V+5 (high pf) & 1.90 & \\
V+5 (low pf) & 3.91 & \\
\hline
\end{tabular}

predation rate will prevail to promote the population abundances. Our study reported that relative high predation rate could promote the hard clam abundances in relation to predators that selectively captured infected hard clam. Our results also implicate that predator-induced modifications in host behavior could have large negative or positive effects on host growth, the sign and magnitude of which were dependent on relative species density and resource dynamics (Fig. 8).
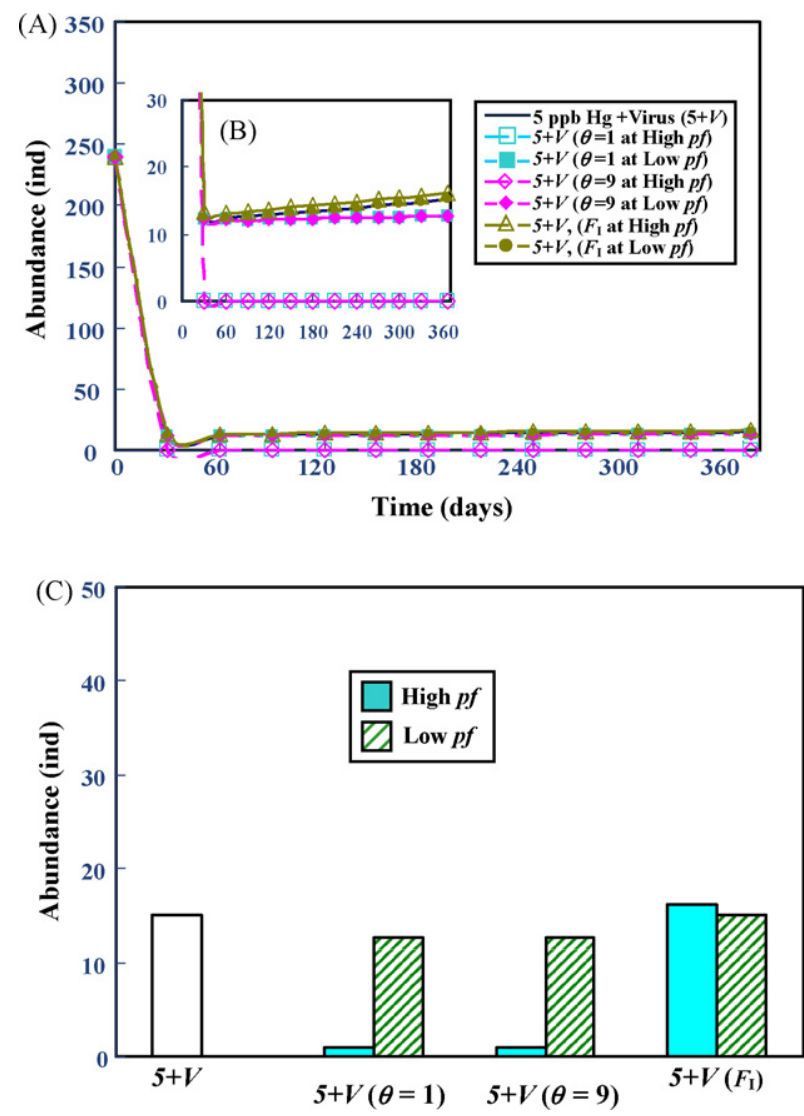

Fig. 6 - Simulations of host-pathogen-predator interactions varied with different levels of predation attack rates $(p f)$ at virus $+5 \mu \mathrm{g} \mathrm{L}^{-1} \mathrm{Hg}(\mathrm{V}+5)$ setting. (A) Dynamics of hard clam exposed to $V+5$ at $\theta=1,5$, and $F_{I}(\theta \rightarrow \infty)$. (B) A 1-year simulation of predation effects on hard clam exposed to $\mathrm{V}+\mathbf{5}$ setting with high/low predation control.
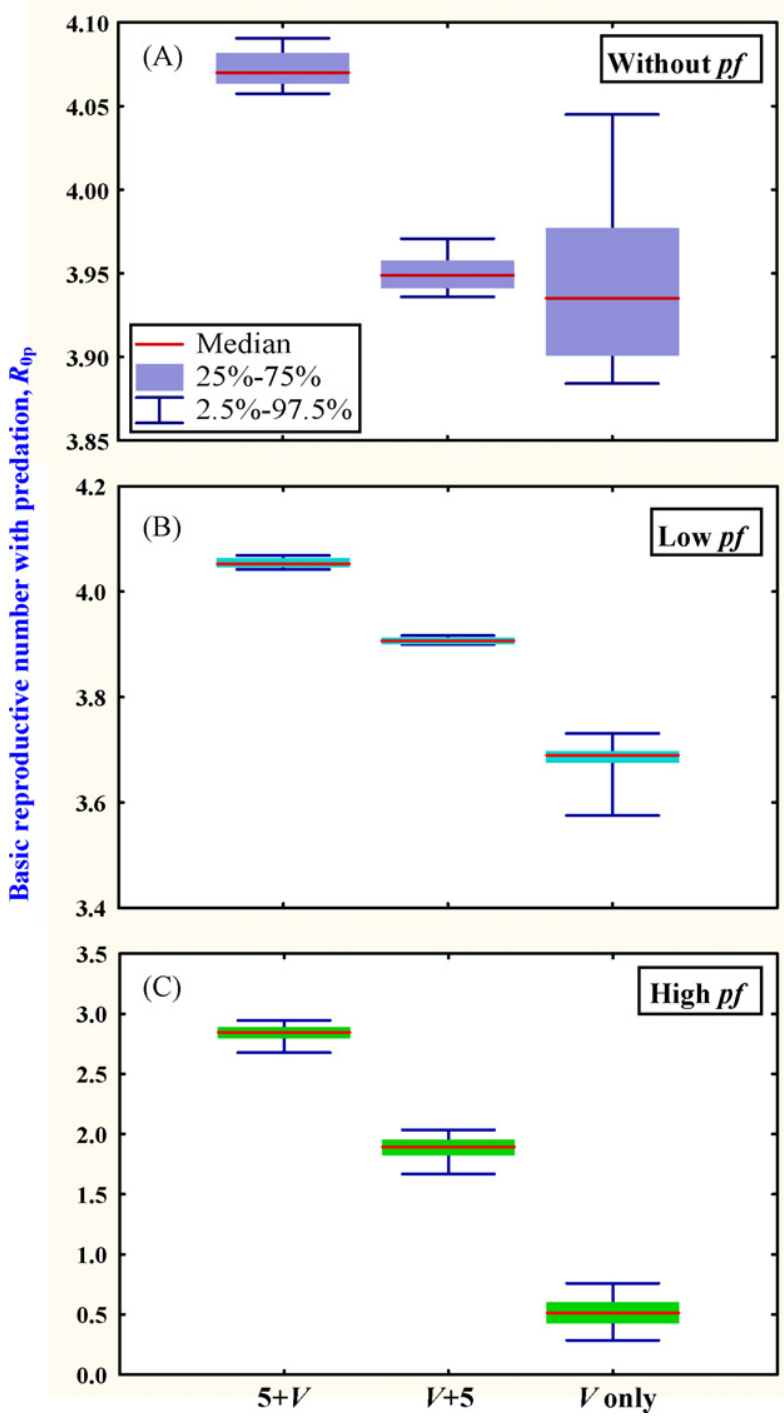

Fig. 7 - Box and whisker plot representations of the basic reproductive number with/without predator control $\left(R_{0}\right.$, $R_{0 P}$ ). (A) $R_{0}$ without predation control. (B) $R_{0 P}$ with low level predation control. (C) $R_{0 P}$ with high level predation control. 


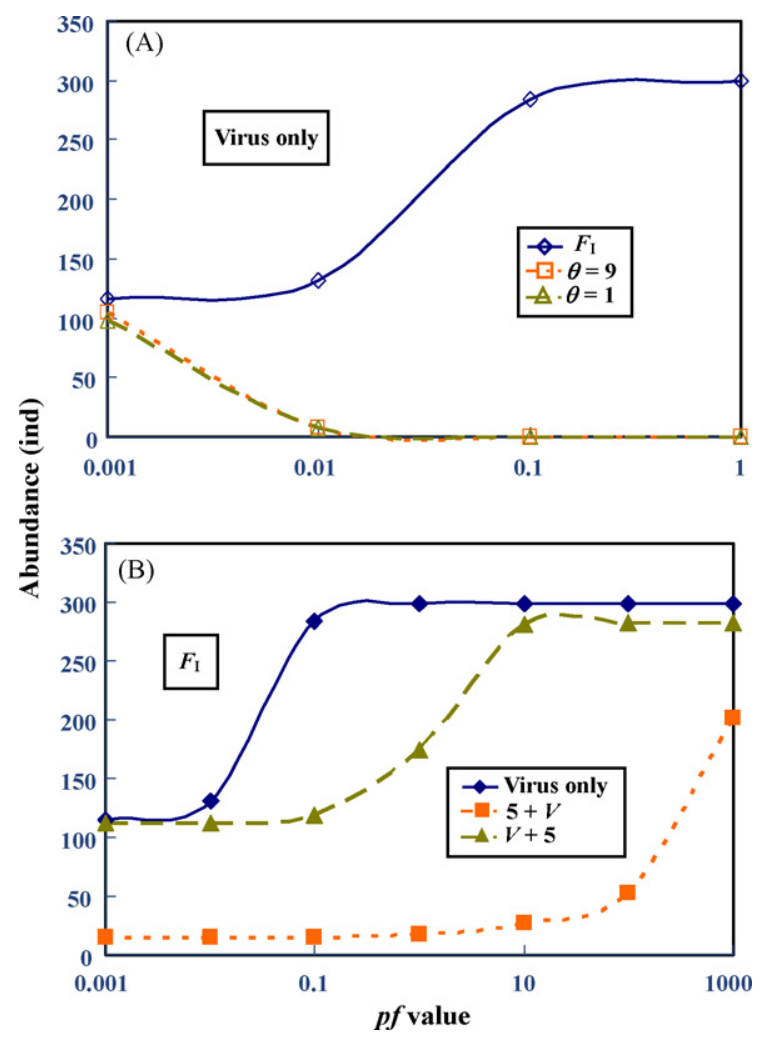

Fig. 8 - Control of predation affects hard clam population abundances at different setting for 1-year simulation. (A) $\theta$-Dependent predation control affecting hard clam abundances virus only setting. (B) Scenario-dependent predation control affecting hard clam population abundances at selective predation $F_{I}(\theta \rightarrow \infty)$ condition.

Our results indicate that predator control causes an increase in host growth in the abundance of hard clam populations under Hg-stressed birnavirus environment. This can be shown in a simple population model: $N(t+1)=$ $N(t) e^{-\left(M+M_{\mathrm{V}}+P\right)}+N_{\mathrm{p}}(\mathrm{t})$ where $N(\mathrm{t})$ is hard clam abundance and $N_{p}(t)$ is the increased abundance due to predator control effort at time $t$, and $M, M_{V}$, and $P$ are natural, infection, and predation mortalities, respectively. Explicitly, as the level of infection and predation mortalities increase, the population dynamics are increasingly dominated by $N_{p}(t)$, and at the limit the population growth attributable to the predator control effort. Thus, one would expect predation to increase population abundance in a typical setting. We have shown a rather counterintuitive consequence of predator-induced positive effects on hard clam growth. It is plausible that predators in aquatic ecosystem can have an indirect positive effect on their prey through the mechanisms outlined in this paper, and that the general mechanisms could also operate in aquatic ecosystem with multiple species within trophic levels.

Predation pressure and competitive interactions are recognized as important aspects of ecosystem husbandry and management (Gibbs, 2004; Stotz et al., 2006; Greene and Grizzle, 2007). Both theoretical and experimental studies of these interactions on the effects of population dynamics pos- itively or negatively have investigated the host growth rate through induced modifications of host behavior and have recommended the suitability of alternative strategies for fisheries and ecosystem managers (Grenfell and Dobson, 1995; Mesa et al., 1998; Iguchi et al., 2003; Duffy et al., 2005; Craig et al., 2006; Trzcinski et al., 2006; Stotz et al., 2006; Greene and Grizzle, 2007). Table 4 can be used as an optimal management strategy in hard clam-birnavirus-predator scenarios, aiding in designing the most efficient and feasible disease management strategy through the predation control efforts. Future studies that investigate aquatic ecosystem host-pathogen-predator interactions at the level of pathogen manipulation and predator foraging behavior on predator-prey communities will hopefully shed light on this intriguing possibility.

In the present study, several improvements have been made to the previous bioenergetic MPM-SIM model (Liao and Yeh, 2007). We have added predator-prey interactions and interactions among pathogens, prey, and predators associated with selective predation to the bioenergetic MPM-SIM model. We did not explicitly examine the sensitivity of our model to input parameters. Implicitly, based on the model simulations featuring in Figs. 3-6 and 8 the levels of predator attack rate $(p f)$ on degree of predator selectivity $\left(\theta\right.$ and $F_{\mathrm{I}}$ ) and Hg-stressed birnavirus settings (V only, $\mathrm{Hg}+\mathrm{V}$ or $\mathrm{V}+\mathrm{Hg}$ ) were expected to be most sensitive to changes in the abundance in the hard clam populations and basic reproductive number. Results from our study have implications for both the approach to and scale of other aquatic ecosystem field studies.

The scenarios reported here could not have been detected in a short-term study and thus seem poorly suited for analysis by a priori hypothesis testing. These points emphasize the potential significance for helping ecosystem scientists in their experimental setups. Our results are relevant to understanding population dynamics of disease transmission or biological invasions in ecosystem species (Hilker et al., 2005); because they demonstrate that adding another predator effort to an aquatic ecosystem under top-down control has predictable effects on aquaculture species populations under the host-pathogen-predator framework.

In conclusion, our results provided the model-based evidence to show that predation affects host-pathogen interactions in the abundance of aquatic ecosystem species populations. Obviously, this safety increases if predation control results in both higher predictability and increasing populations. In the future study, we intend to include a measure of variability in most of the parameters in the model to reflect the confidence limits on our estimates of hard clam abundance. The relationship between an individual predator consumption rate and prey density is termed functional response, and is a key factor regulating the population dynamics of predator-prey relationships. Functional response of a predator reflects its searching ability, handling effect, and maximum number of prey (Hall et al., 2005, 2006; Fenton and Rands, 2006). Model structure in relation to the functional response associated with heterogeneity in predation pressure and predator infection in both time and space on the impacts of prey population is thus worthwhile to explore. 


\section{REFE RE N C E S}

Anderson, R.M., May, R.M., 1991. Infectious Diseases of Humans: Dynamics and Control. Oxford University Press, New York, NY.

Beyers, D.W., Rice, J.A., Clements, W.H., Henry, C.J., 1999. Estimating physiological cost of chemical exposure: integrating energetics and stress to quantify toxic effects in fish. Can. J. Fish. Aquat. Sci. 56, 814-822.

Caswell, H., 2001. Matrix Population Models: Construction, Analysis, and Interpretation, second ed. Sinauer Associates, Sunderland, MA, USA.

Choo, K., Williams, P.D., Day, T., 2003. Host mortality, predation and the evolution of parasite virulence. Ecol. Lett. 6, 310-315

Chou, H.Y., Chang, S.J., Lee, H.Y., Chiou, Y.C., 1998. Preliminary evidence for the effect of heavy metal cations on the susceptibility of hard clam (Meretrix lusoria) to clam birnavirus infection. Fish Pathol. 33, 213-219.

Craig, J.K., Burke, B.J., Crowder, L.B., Rice, J.A., 2006. Prey growth and size-dependent predation in juvenile estuarine fishes: experimental and model analyses. Ecology 87, 2366-2377.

Duffy, M.A., Hall, S.R., Tessier, A.J., Huebner, M., 2005. Selective predators and their parasitized prey: are epidemics in zooplankton under top-down control? Limnol. Oceanogr. 50, 412-420.

Fenton, A., Rands, S.A., 2006. The impact of parasite manipulation and predator foraging behavior on predator-prey communities. Ecology 87, 2832-2841.

Fregadolli, C.H., 2003. Laboratory analysis of predation by cyclopoid copepods on first-feeding larvae of cultured Brazilian fishes. Aquaculture 228, 123-140.

Gibbs, M.T., 2004. Interactions between bivalve shellfish farms and fishery resources. Aquaculture 240, 267-296.

Greene, J.K., Grizzle, R.E., 2007. Successional development of fouling communities on open ocean aquaculture fish cages in the western Gulf of Maine, USA. Aquaculture 262, 289-301.

Grenfell, B.T., Dobson, A.P., 1995. Ecology of Infectious Diseases in Natural Population. Cambridge University Press, Cambridge, UK.

Hall, S.R., Duffy, M.A., Cáceres, C.E., 2005. Selective predation and productivity jointly drive complex behavior in host-parasite systems. Am. Nat. 165, 70-81.

Hall, S.R., Tessier, A.J., Duffy, M.A., Huebner, M., Cáceres, C.E., 2006. Warmer does not have to mean sicker: temperature and predators can jointly drive timing of epidemics. Ecology 87 , 1695-1864.

Hilker, F.M., Lewis, M.A., Seno, H., Langlais, M., Malchow, H., 2005. Pathogens can slow down or reverse invasion fronts of their hosts. Biol. Invasions 7, 817-832.
Hudson, P.J., Dobson, A.P., Newborn, D., 1992. Do parasites make prey vulnerable to predation? Red grouse and parasites. J. Anim. Ecol. 61, 681-692.

Iguchi, K., Ogawa, K., Nagae, M., Fuminari, I., 2003. The influence of rearing density on stress response and disease susceptibility of ayu (Plecoglossus altivelis). Aquaculture 220, 515-523.

Johnson, P.T.J., Stanton, D.E., Preu, E.R., Forshay, K.J., Carpenter, S.R., 2006. Dining on disease: how interactions between infection and environment affect predation risk. Ecology 87, 1973-1980.

Lafferty, K.D., 1992. Foraging on prey that are modified by parasites. Am. Nat. 140, 854-867.

Lafferty, K.D., Morris, A.K., 1996. Altered behavior of parasitized killifish increases susceptibility to predation by bird final hosts. Ecology 77, 1390-1397.

Liao, C.M., Chang, C.F., Yeh, C.H., Chen, S.C., Chiang, K.C., Chio, C.P., Chou, B.Y.H., Jou, L.J., Lien, G.W., Lin, C.H., Shen, H.H., Wu, G.D., 2006. Metal stresses affect the population dynamics of disease transmission in aquaculture species. Aquaculture 257, 321-332.

Liao, C.M., Yeh, C.H., 2007. Hard clam Meretrix lusoria to Hg-stressed birnavirus susceptibility revealed through stage-structured disease transmission dynamics. Aquaculture 264, 101-118.

Mesa, M.G., Poe, T.P., Gadomski, D.M., Petersen, J.H., 1994. Are all prey created equal? A review and synthesis of differential predation on prey in substandard condition. J. Fish Biol. 45 (Suppl. A), 81-96.

Mesa, M.G., Poe, T.P., Maule, A.G., Schreck, C.B., 1998. Vulnerability to predation and physiological stress responses in juvenile Chinook salmon (Oncorhynchus tshawytscha) experimentally infected with Renibacterium salmoninarum. Can. J. Fish. Aquat. Sci. 55, 1599-1606.

Packer, C., Holt, R.D., Hudson, P.J., Lafferty, K.D., Dobson, A.P., 2003. Keeping the herds healthy and alert: implications of predator control for infectious disease. Ecol. Lett. 6, 797-802.

Price, C.S., Schreck, C.B., 2003. Effects of bacterial kidney disease on saltwater preference of juvenile spring Chinook salmon, Oncorhynchus tshaqytscha. Aquaculture 222, 331-341.

Stotz, W.B., Caillaux, L., Aburto, J., 2006. Interactions between the Japanese abalone Haliotis discus hannai (Ino 1953) and Chilean species: consumption, competition, and predation. Aquaculture 255, 447-455.

Tsai, J.W., Liao, C.M., 2006. Mode of action and growth toxicity of arsenic to tilapia Oreochromis mossambicus can be determined bioenergetically. Arch. Environ. Contam. Toxicol. 50, 144-152.

Trzcinski, M.K., Mohn, R., Bowen, W.D., 2006. Continued decline of an Atlantic cod population: how important is gray seal predation? Ecol. Appl. 16, 2276-2292. 